\title{
Ocena zdolności kombinacyjnej wybranych form rodzicielskich borówki wysokiej (Vaccinium corymbosum L.) dla siły wzrostu siewek
}

\author{
Assessment of the combining ability of selected highbush blueberry (Vaccinium \\ corymbosum L.) parental forms for seedling's growth
}

\section{Stanisław Pluta ${ }^{\circledR u k a s z ~ S e l i g a ~}$}

Instytut Ogrodnictwa, ul. Konstytucji 3 Maja 1/3, 96-100 Skierniewice,

$\triangle$ e-mail: Stanislaw.Pluta@inhort.pl

\begin{abstract}
Celem badań było określenie wartości hodowlanej 12 genotypów rodzicielskich borówki wysokiej (Vaccinium corymbosum L.) na podstawie oceny ich ogólnej i specyficznej zdolności kombinacyjnej (GCA i SCA) dla siły wzrostu siewek. Materiał badawczy stanowiła populacja 2100 siewek F uzyskanych z programu krzyżowania w 2014 roku. Krzyżowania 7 form matecznych (ㅇ) - 'Aurora', 'Bluecrop', 'Brigitta Blue', 'Chandler', 'Draper', 'Duke', 'Northland' oraz 5 form ojcowskich $(\precsim)$ - 'Earliblue', 'KazPliszka', 'Polaris', 'Toro', 'Weymouth' były wykonane w układzie czynnikowym (7x5). Jesienią 2014 r. założono doświadczenie polowe w układzie kompletnych bloków losowych, w 4 powtórzeniach, z 15 siewkami na poletku. W 2019 r. wykonano ocenę fenotypową populacji siewek pod kątem siły wzrostu roślin. Stwierdzono, że siewki różniły się istotnie tą cechą morfologiczną roślin. Na podstawie wyników oceny fenotypowej populacji siewek określono efekty GCA dla 12 rodzicielskich odmian i efekty SCA dla 35 rodzin mieszańcowych dla tej cechy. Analiza statystyczna wykazała, że formy rodzicielskie różniły się istotnie pod względem zdolności kombinacyjnej (efekty GCA i SCA) dla siły wzrostu. Formy rodzicielskie posiadające istotne i dodatnie wartości efektów GCA były potencjalnie przydatnymi dawcami genów determinujących silny wzrost, natomiast istotne i negatywne wartości efektów innych form rodzicielskich wskazywały na pogorszenie tej cechy u ocenianego potomstwa. Statystycznie istotne dodatnie lub ujemne wartości efektów SCA były wynikiem interakcji genetycznej obu form rodzicielskich w tych rodzinach mieszańcowych, a zatem mogły wpłynąć na poprawę lub pogorszenie siły wzrostu siewek borówki wysokiej.
\end{abstract}

Słowa kluczowe: borówka wysoka, GCA, hodowla, ocena fenotypowa, SCA, siła wzrostu.

\begin{abstract}
The aim of the study was to determine the breeding value of 12 highbush blueberry (Vaccinium corymbosum L.) parental genotypes based on the estimation of their general and specific combining ability (GCA and SCA) for seedling growth. The research material was a population of $2,100 \mathrm{~F}$, plants obtained from the 2014 crossing program. Crosses of 7 maternal forms (ㅇ) - ,Aurora', ,Bluecrop', ,Brigitta Blue', ,Chandler', ,Draper', ,Duke', ,Northland' - and 5 paternal forms $\left({ }^{\Uparrow}\right)$ - ,Earliblue', ,KazPliszka', ,Polaris', ,Toro', ,Weymouth' - were made in a factorial design (7x5). In autumn 2014, the field experiment was established in complete randomized block design, in 4 replications, with 15 seedlings per plot. In 2019, a phenotypic evaluation of the seedling population was done for plant growth. We found that the seedlings differed significantly in this plant morphological trait. Based on the results of the phenotypic evaluation of the seedling population, the GCA effects for 12 parental cultivars and SCA effects for 35 hybrid families for this trait were determined. Statistical analysis showed that the parental forms differed significantly in their combining ability (GCA and SCA effects) for plant growth. The parental forms possessing significant and positive values of GCA effects were potentially useful donors of genes determining strong growth, while, conversely, significant and negative effects in other parental forms influenced the deterioration of this trait in the assessed offspring. Statistically significant positive or negative values of SCA effects were the results of genetic interaction of both parental forms within these hybrid families, and could, therefore, inform the breeder of the improvement or deterioration of plant growth in blueberry seedlings.
\end{abstract}

Key words: highbush blueberry, breeding, GCA, phenotypic evaluation, plant growth, SCA

\section{Wstęp}

W tradycyjnej hodowli roślin uprawnych, w tym borówki wysokiej (Vaccinium corymbosum L.), ważny jest wybór odpowiednich form rodzicielskich do programów krzyżowań. Poznanie wartości hodowlanej form rodzicielskich i genetyczne określenie cech ilościowych w populacji, poziom i sposób ich dziedziczenia zwiększają prawdopodobieństwo szybkiego osiagnięcia celów hodowlanych. Wartość hodowlana genotypu rodzicielskiego jest określana na podstawie efektów ogólnej (GCA) i specyficznej zdolności kombinacyjnej (SCA), korelacji genetycznej między cechami, wariancji genetycznej cech i ich odziedziczalności (Sprague i Tatum, 1942; Sherrif i in., 1985; Żurawicz i in., 2006; Pluta i in., 2014). 
Ogólna zdolność kombinacyjna (GCA) formy rodzicielskiej dla rozważanej cechy ilościowej określa jej możliwość do przekazywania średniego poziomu tej cechy potomstwu (Baker, 1978; Vieira i in., 2009). Efekt GCA jest miarą addytywnego działania genów formy rodzicielskiej na tę cechę (Griffing 1956 a, b). Genotypy rodzicielskie użyte w programach krzyżowań charakteryzujące się istotnie dodatnimi efektami GCA dla danej cechy znacznie zwiększają prawdopodobieństwo uzyskania siewek (mieszańców) o pożądanych wartościach tej cechy (Bestfleisch i in., 2014; Masny i in., 2014; Pluta i in., 2014).

Specyficzna zdolność kombinacyjna (SCA) pary form rodzicielskich dla danej cechy jest efektem interakcji genetycznej obu rodziców, objawiającej się w ich potomstwie (Griffing, 1956 a, b; Baker, 1978). Efekt SCA jest wynikiem nieaddytywnego działania genów (dominacja i epistaza). Pokazuje różnicę między średnią wartością cechy u potomstwa (pełne rodzeństwo dwóch form rodzicielskich) a sumą efektów GCA dla tych form rodzicielskich (Bestfleisch i in., 2014).

Efekty GCA i SCA form rodzicielskich testowane w układach krzyżowań są miernikami ich wartości hodowlanej dla rozważanych cech użytkowych. Oznacza to przydatność genotypów rodzicielskich do programów hodowlanych ukierunkowanych na poprawę tych cech u nowych odmian (Baker, 1978; Masny i in., 2005; 2016; Bestfleisch i in., 2014; Pluta i Żurawicz 2014). Sukces wyboru wartościowych form rodzicielskich w programie hodowlanym może być dodatkowo zwiększony, jeśli rozważa się efekty SCA poszczególnych kombinacji rodzicielskich. Ponadto, zróżnicowanie efektów SCA w danym programie krzyżowania wskazuje na duże znaczenie interakcji genetycznej obu form rodzicielskich w dziedziczeniu cech u potomstwa (Baker, 1978). Zarówno efekty GCA, jak i SCA mają wartości istotne dodatnie i ujemne. Oznacza to, że testowane formy rodzicielskie w programach hodowlanych mogą mieć pozytywny lub negatywny wpływ na występowanie cech ocenianych siewek.

Celem badań było określenie ogólnej i specyficznej zdolności kombinacyjnej (GCA i SCA) 12 form rodzicielskich borówki amerykańskiej i 35 rodzin mieszańcowych na podstawie oceny fenotypowej siły wzrostu siewek rosnących w doświadczeniu polowym.

\section{Materiały i Metody}

Materiał badawczy. Materiał roślinny stanowiła populacja 2100 siewek (mieszańców) pokolenia $\mathrm{F}_{1}$ borówki wysokiej należących do 35 rodzin mieszańcowych, uzyskana z programu krzyżowań 12 odmian rodzicielskich, w układzie czynnikowym $(7 \times 5)$. Genotypami rodzicielskimi było 7 form matecznych (P) - 'Aurora', 'Bluecrop', 'Brigitta Blue', 'Chandler', 'Draper', 'Duke' i 'Northland' oraz 5 form ojcowskich (đ) - 'Earliblue', 'KazPliszka', 'Polaris', 'Toro' i 'Weymouth', które użyto w programie krzyżowań, wykonanym wiosną w 2014 roku. Odmiany rodzicielskie pochodzą z różnych rejonów geograficznych (USA, Nowa Zelandia i Polska) oraz charakteryzują się wieloma wartościowymi cechami użytkowymi i dużą zmiennością fenotypową i genetyczną (siłą wzrostu i pokrój krzewu, termin kwitnienia i dojrzewania owoców, plonowanie, masa i atrakcyjność owoców oraz, odporność na główne choroby i szkodniki). Siewki należące do 35 rodzin mieszańcowych wysadzono jesienią 2014 roku w doświadczeniu polowym w Sadzie Pomologicznym w Skierniewicach. Doświadczenie założono w układzie bloków kompletnych, w 4 powtórzeniach z 15 siewkami na poletku. Siewki rosną w rzędach wyłożonych agrowłókniną. Uprawa, pielęgnacja siewek, nawożenie gleby i dokarmianie roślin prowadzone były zgodnie z zaleceniami dla plantacji towarowych borówki wysokiej. Wiosną w rzędy krzewów, stosowano siarczan amonu $(21 \% \mathrm{~N})$ w dawce przeliczeniowej 100 $\mathrm{kg} / \mathrm{ha}$, podzielonej (50\%:50\%), w odstępie 3-4 tygodni. Po kwitnieniu krzewów (II poł. maja) rozsiewano wieloskładnikowy nawóz Yara Mila Complex (12-11-18+Mg+S+Mikro) w dawce $150 \mathrm{~kg} / \mathrm{ha}$. Jesienią (koniec września) stosowano siarczan potasu (42\% K2O), w dawce $120 \mathrm{~kg} / \mathrm{ha}$. W sezonie wegetacyjnym siewki były nawadniane przy użyciu systemu kroplowego, 2 razy dziennie, rano i pod wieczór. Wczesną wiosną w rzędy roślin na agrowłókninę zastosowano trociny, które co roku są uzupełniane. Regulowanie zachwaszczenia prowadzono poprzez pielenie ręczne lub mechanicznie, w miarę potrzeby stosowano herbicydy (Fusilade Forte 150 EC i Basta $150 \mathrm{SL}$ ). Na podstawie monitoringu siewek w ograniczonym zakresie stosowano integrowaną ochronę roślin przed chorobami grzybowymi i szkodnikami, (szkodniki: Calypso 480 SC, Spin Tor 240 SC, choroby grzybowe: Switch 62,5 WG, Topsin M 500 $\mathrm{SC}$ ), zgodnie z zaleceniami Poradnika Integrowanej Ochrony Roślin Jagodowych na rok 2019. Ochrona przed ptakami (szpaki, kwiczoły, kosy i gołębie), które stanowią poważny problem w uprawie borówki, polegała na rozciągnięciu siatki polietylenowej na drutach przymocowanych w górnej części do impregnowanych drewnianych słupków o wys. $3,5 \mathrm{~m}$. 
Warunki pogodowe określono na podstawie danych meteorologicznych ze stacji METOSCOMPACT (firmy Pessl Instruments) Przebieg warunków pogodowych w każdym miesiącu sezonu wegetacyjnego $\mathrm{w}$ roku 2019 przedstawiono w tabeli 1.

Najniższą temperaturę powietrza na wysokości $2 \mathrm{~m}$ od poziomu gleby odnotowano 16 kwietnia $\left(-4,92^{\circ} \mathrm{C}\right)$. Maksymalną temperaturę stwierdzono w czerwcu $\left(36,6^{\circ} \mathrm{C}\right)$, chociaż wysokie temperatury panowały także w miesiącach letnich (lipiec-wrzesień). Opady atmosferyczne występowały cyklicznie w ciągu całego okresu wegetacyjnego w roku 2019. Największe opady deszczu odnotowano w maju, sierpniu i wrześniu. W pozostałych miesiącach tego roku notowano słabsze opady atmosferyczne, które nie miały wpływu na słabszy wzrost krzewów borówki wysokiej w prowadzonym doświadczeniu, gdyż stosowano nawodnienie kroplowe roślin.

Ocena fenotypowa. W sezonie wegetacyjnym 2019 roku wykonano ocenę fenotypową siewek pod względem siły wzrostu siewek. Pomiar wysokości i szerokości $(\mathrm{cm})$ wykonano w dwóch terminach: wiosną, na początku wegetacji roślin oraz jesienią, po zakończeniu wzrostu i wegetacji. Pomiar wysokości $(\mathrm{cm})$ - siewki mierzono indywidualnie od powierzchni ziemi do wierzchołka rośliny; pomiar szerokości $(\mathrm{cm})$ - siewki mierzono w kierunku poprzecznym do rzędów roślin.

Zdolność kombinacyjna. Na podstawie wyników oceny fenotypowej siły wzrostu siewek borówki wysokiej oszacowano ogólną zdolność kombinacyjną (efekty GCA) dla 12 odmian rodzicielskich borówkiwysokiej ispecyficznązdolnośćkombinacyjną (efekty SCA) dla 35 rodzin mieszańcowych.
Analiza statystyczna. Uzyskane wyniki (dane) poddano analizie statystycznej w dwóch etapach. $\mathrm{Na}$ podstawie obserwacji oraz pomiarów siły wzrostu roślin obliczono średnie arytmetyczne dla każdego poletka doświadczalnego. Srednie te użyto do ich wstępnego opracowania statystycznego metodą jednoczynnikowej analizy wariancji (ANOVA) wg modelu losowanych bloków, w którym czynnikiem są rodziny mieszańców. Po stwierdzeniu istotnego zróżnicowania średnich tej cechy u badanych mieszańców wykonano analizę wariancji dla kompletnego układu czynnikowego (97 x $\lesssim 5)$, w celu oszacowania efektów ogólnej (GCA) i specyficznej (SCA) zdolności kombinacyjnej dla badanej cechy morfologicznej roślin. Wszystkie obliczenia, dotyczące estymacji efektów GCA i SCA w powyższym modelu, analizę wariancji i szczegółowego testowania jednoczesnego wykonano za pomocą programu komputerowego SERGEN, opracowanego przez naukowców z Instytutu Genetyki Roślin PAN w Poznaniu (Caliński i in., 2003).

\section{Wyniki \\ Ocena fenotypowa}

Wyniki oceny siły wzrostu badanych siewek borówki wysokiej (określonej na podstawie pomiaru wysokości i szerokości roślin) przedstawiono w tabeli 2.

Oceniane siewki borówki wysokiej w doświadczeniu polowym wykazywały umiarkowaną siłę wzrostu. Szczegółowa analiza wyników uzyskanych w I terminie (wiosna) i w II terminie (jesień) wskazuje na zwyżkowy trend w sile wzrostu siewek. W sezonie wegetacyjnym 2019 roku siewki wykazywały silniejszy wzrost (wysokość i szerokość roślin) w obrębie poszczególnych rodzin

Tabela 1.

Table 1.

Minimalne i maksymalne temperatury oraz suma opadów w okresie wegetacji w roku 2019, środkowa Polska

Minimum and maximum temperatures and total precipitation during the growing season in 2019, central Poland

\begin{tabular}{|c|c|c|c|c|}
\hline \multirow[b]{2}{*}{ Miesiące/Months } & \multicolumn{3}{|c|}{ Temperatura powietrza $\left({ }^{\circ} \mathrm{C}\right) /$ Air temperature $\left({ }^{\circ} \mathrm{C}\right)$} & \multirow{2}{*}{$\begin{array}{c}\text { Suma opadów }(\mathrm{mm}) \\
\text { Sum of precipitation }(\mathrm{mm})\end{array}$} \\
\hline & $\begin{array}{l}\text { Minimalna/ } \\
\text { Min }\end{array}$ & $\begin{array}{l}\text { Maksymalna/ } \\
\text { Max. }\end{array}$ & $\begin{array}{l}\text { Średnia/ } \\
\text { Average }\end{array}$ & \\
\hline Marzec/March & $-3,49$ & 17,35 & 5,73 & 34,60 \\
\hline Kwiecień/April & $-4,92$ & 27,59 & 9,51 & 17,00 \\
\hline Maj/May & $-1,99$ & 26,05 & 12,56 & 61,00 \\
\hline Czerwiec/June & 7,68 & 36,60 & 24,63 & 46,20 \\
\hline Lipiec/July & 6,49 & 33,48 & 18,24 & 55,40 \\
\hline Sierpień/August & 6,25 & 33,48 & 19,74 & 77,80 \\
\hline Wrzesień/September & 2,59 & 31,44 & 13,79 & 82,80 \\
\hline Pażdziernik/October & $-3,25$ & 23,78 & 10,23 & 21,60 \\
\hline
\end{tabular}


mieszańcowych, jak i pomiędzy nimi, stwierdzony w II ocenie jesienią, po zakończeniu wegetacji roślin (tab. 2).

Średnie wyniki pomiarów wysokości i szerokości siewek obu terminów wskazują, że najsilniejszym wzrostem charakteryzowały się siewki borówki wysokiej należące do następujących rodzin mieszańcowych: 'Aurora' x 'Polaris', 'Bluecrop' $\mathrm{x}$ 'Polaris', 'Bluecrop' $\mathrm{x}$ 'KazPliszka', 'Bluecrop' $\mathrm{x}$ 'Toro', 'Bluecrop' $\mathrm{x}$ 'Weymouth', 'Chandler' x 'Polaris', 'Duke' x 'Earliblue', 'Duke' x 'Toro', 'Duke' x 'Weymouth', 'Northland' $\mathrm{x}$ 'Toro' i 'Northland' $\mathrm{x}$ 'Weymouth'. Najsłabszy wzrost siewek stwierdzono dla 9 rodzin mieszańcowych pochodzacych ze skrzyżowania: 'Aurora' $\mathrm{x}$ 'Weymouth', 'Aurora' $\mathrm{x}$ 'KazPliszka', 'Brigitta B.' x 'KazPliszka', 'Brigitta B.' x 'Polaris', 'Brigitta B.' $\mathrm{x}$ 'Toro', 'Chandler' $\mathrm{x}$ 'Earliblue', 'Chandler' $\mathrm{x}$ 'KazPliszka', 'Chandler' $\mathrm{x}$ 'Weymouth', 'Draper' x 'Toro', 'Northland' $x$ 'KazPliszka' i 'Northland' $\mathrm{x}$ 'Polaris'. Rośliny należące do pozostałych rodzin mieszańcowych cechowały się średnią siłą wzrostu (tab. 2).

\section{Zdolność kombinacyjna (GCA i SCA)}

Wyniki analizy statystycznej dotyczące ogólnej i specyficznej zdolności kombinacyjnej (GCA i SCA) dla siły wzrostu siewek borówki wysokiej zamieszczono w tabelach 3-4. Efekty GCA i SCA przyjmują dodatnie i ujemne wartości i mogą wpływać pozytywnie lub negatywnie na przekazywanie cech użytkowych u analizowanego potomstwa.

\section{Efekty GCA}

Wartości efektów GCA (dodatnie i ujemne) dla 12 odmian rodzicielskich borówki wysokiej pod względem siły wzrostu określonej na podstawie pomiaru wysokości i szerokości wszystkich siewek wykonanych w 2019 roku przedstawiono w tabeli 3.

Analiza wyników w tabeli 3 pokazuje, że dla wysokości siewek borówki istotne statystycznie i dodatnie wartości efektów GCA uzyskano dla 2 form (odmian) matecznych: 'Bluecrop' i 'Duke'. Oznacza to, że obie odmiany użyte jako formy rodzicielskie w programie krzyżowań przekazują potomstwu zdolność do wytwarzania wyższych krzewów, w porównaniu do pozostałych badanych odmian. Istotnie ujemne wartości efektów GCA dla tej cechy roślin stwierdzono dla jednej odmiany matecznej, tj. 'Brigitta Blue' oraz dla jednej odmiany ojcowskiej 'KazPliszka'. Odmiany te w krzyżowaniach są więc donorami genów warunkujących słaby wzrost $\mathrm{u}$ potomstwa siewek borówki wysokiej. W przypadku szerokości krzewów istotne statystycznie i dodatnie wartości efektów GCA uzyskano dla 2 odmian matecznych: 'Bluecrop' i 'Duke'. Natomiast istotnie ujemne wartości efektów GCA dla tej cechy morfologicznej oszacowano dla 2 innych odmian matecznych: 'Brigitta Blue' i 'Chandler' oraz dla jednej odmiany ojcowskiej 'KazPliszka'. W praktyce te ostatnie trzy formy rodzicielskie użyte $\mathrm{w}$ programach krzyżowań $z$ dużym prawdopodobieństwem przekazują potomstwu zdolność do tworzenia krzewów węższych i bardziej wzniesionych (istotne i ujemne efekty GCA), zaś dwie wymienione wcześniej - szerszych i bardziej rozłożystych (istotne i dodatnie efekty GCA).

\section{Efekty $S C A$}

Efekty specyficznej zdolności kombinacyjnej (SCA) oszacowane dla siły wzrostu siewek, należących do 35 rodzin mieszańcowych, przedstawiono w tabeli 4. Wartości efektów SCA (dodatnie lub ujemne) oceniane dla konkretnej pary form rodzicielskich mogą wpływać pozytywnie lub negatywnie na uwarunkowanie danej cechy u populacji siewek.

Analizawyników wskazuje,że oszacowane efekty SCA dla wysokości i szerokości siewek borówki wysokiej były istotnie zróżnicowane dla kilku rodzin mieszańcowych. Dla wysokości roślin istotne statystycznie i dodatnie wartości efektów SCA w roku 2019 uzyskano tylko dla 2 rodzin mieszańcowych: 'Aurora' x 'Polaris' i 'Chandler' x 'Polaris'. Należy zatem oczekiwać, że potomstwo uzyskane w wyniku genetycznej interakcji obu form rodzicielskich będzie odznaczać się silnym wzrostem. Istotnie negatywne wartości SCA dla tej cechy roślin obliczono dla innych 4 kombinacji krzyżowań: 'Aurora' x 'Weymouth', 'Draper' x 'Toro', 'Duke' x 'Polaris' i 'Northland' x 'Polaris'. Oznacza to, że w przypadku tych rodzin mieszańcowych genetyczne współdziałanie obu odmian (form) rodzicielskich warunkuje i słaby wzrost uzyskanego potomstwa (tab. 4).

W przypadku drugiej cechy morfologicznej (szerokości roślin) istotne i dodatnie wartości efektów SCA uzyskano dla 4 rodzin mieszańców: 'Aurora' x 'Polaris', 'Chandler' $x$ 'Polaris', 'Draper' $x$ 'KazPliszka' i 'Northland' $x$ 'Weymouth'. Zatem siewki borówki wysokiej należące do tych rodzin mieszańcowych będą wytwarzać krzewy szersze i bardziej rozłożyste. Istotne ujemne wartości efektów SCA dla tej cechy roślin uzyskano dla innych 3 rodzin mieszańcowych: 'Aurora' $\mathrm{x}$ 'Weymouth', 'Draper' $\mathrm{x}$ 'Toro' i 'Northland' x 'Polaris'. Ujemna wartość oszacowanego efektu SCA wskazuje 
na duże prawdopodobieństwo, że siewki należą- się węższymi i bardziej wzniesionymi krzewami ce do tych rodzin mieszańcowych będą cechować (tab. 4).

Tabela 2

Table 2

Siła wzrostu siewek borówki wysokiej rosnących w doświadczeniu polowym

Growth strength of highbush blueberry seedlings grown in the field

\begin{tabular}{|c|c|c|c|c|c|c|}
\hline \multirow{3}{*}{ Lp. } & \multirow{3}{*}{$\begin{array}{l}\text { Nr kombinacji } \\
\text { Combination no }\end{array}$} & \multirow{3}{*}{$\begin{array}{l}\text { Rodowód } \\
\text { Pedigree } \\
\quad+x \delta\end{array}$} & \multicolumn{4}{|c|}{ Siła wzrostu siewek Growth strength of seedlings } \\
\hline & & & \multicolumn{2}{|c|}{$\begin{array}{l}\text { Wysokość roślin }(\mathrm{cm}) \\
\text { Plant height }(\mathrm{cm})\end{array}$} & \multicolumn{2}{|c|}{$\begin{array}{l}\text { Szerokość roślin }(\mathrm{cm}) \\
\text { Plant width }(\mathrm{cm})\end{array}$} \\
\hline & & & $\begin{array}{l}\text { Itermin }^{a} \\
1^{\text {st }} \text { term }^{a}\end{array}$ & $\begin{array}{l}\text { II termin } \\
2^{b} \\
2^{\text {nd }} \text { term }^{b}\end{array}$ & $\begin{array}{l}\text { Itermin }^{a} \\
1^{\text {st }} \text { term }^{a}\end{array}$ & $\begin{array}{l}\text { II } \text { termin }^{b} \\
2^{\text {nd }} \text { term }^{b}\end{array}$ \\
\hline 1 & $1 \backslash 1$ & Aurora x Earliblue & 40,3 & 52,6 & 38,0 & 57,4 \\
\hline 2 & $1 \backslash 2$ & Aurora x KazPliszka & 35,1 & 42,9 & 38,2 & 45,7 \\
\hline 3 & $1 \backslash 3$ & Aurora $\mathrm{x}$ Polaris & 50,9 & 66,5 & 51,6 & 65,3 \\
\hline 4 & $1 \backslash 4$ & Aurora $\mathrm{x}$ Toro & 48,7 & 59,0 & 51,4 & 54,2 \\
\hline 5 & $1 \backslash 5$ & Aurora x Weymouth & 26,4 & 32,8 & 29,6 & 33,7 \\
\hline \multicolumn{3}{|c|}{ średnia average } & 40,3 & 50,8 & 41,7 & 51,2 \\
\hline 6 & $2 \backslash 1$ & Bluecrop x Earliblue & 42,1 & 60,5 & 39,9 & 56,0 \\
\hline 7 & $2 \backslash 2$ & Bluecrop x KazPliszka & 46,8 & 67,1 & 47,5 & 66,2 \\
\hline 8 & $2 \backslash 3$ & Bluecrop x Polaris & 48,4 & 66,9 & 48,4 & 62,7 \\
\hline 9 & $2 \backslash 4$ & Bluecrop x Toro & 47,0 & 69,2 & 45,4 & 64,1 \\
\hline 10 & $2 \backslash 5$ & Bluecrop x Weymouth & 52,3 & 68,3 & 58,4 & 71,3 \\
\hline \multicolumn{3}{|c|}{ średnia average } & 47,3 & 66,4 & 47,9 & 64,1 \\
\hline 11 & $3 \backslash 1$ & Brigitta B. x Earliblue & 42,5 & 46,8 & 42,8 & 58,1 \\
\hline 12 & $3 \backslash 2$ & Brigitta B. x KazPliszka & 41,2 & 41,7 & 37,5 & 42,4 \\
\hline 13 & $3 \backslash 3$ & Brigitta B. x Polaris & 32,0 & 44,1 & 34,3 & 45,3 \\
\hline 14 & $3 \backslash 4$ & Brigitta B. $\mathrm{x}$ Toro & 33,9 & 41,1 & 36,3 & 41,3 \\
\hline 15 & $3 \backslash 5$ & Brigitta B. x Weymouth & 36,1 & 50,7 & 37,7 & 48,7 \\
\hline \multicolumn{3}{|c|}{ średnia average } & 37,1 & 44,9 & 37,7 & 47,2 \\
\hline 16 & $4 \backslash 1$ & Chandler x Earliblue & 32,7 & 42,6 & 32,6 & 41,6 \\
\hline 17 & $4 \backslash 2$ & Chandler x KazPliszka & 27,1 & 34,3 & 33,7 & 36,4 \\
\hline 18 & $4 \backslash 3$ & Chandler x Polaris & 52,8 & 72,0 & 48,2 & 65,8 \\
\hline 19 & $4 \backslash 4$ & Chandler $\mathrm{x}$ Toro & 40,6 & 54,1 & 40,6 & 58,1 \\
\hline 20 & $4 \backslash 5$ & Chandler x Weymouth & 30,1 & 40,6 & 29,6 & 38,1 \\
\hline \multicolumn{3}{|c|}{ średnia average } & 36,7 & 48,7 & 36,9 & 48,0 \\
\hline 21 & $5 \backslash 1$ & Draper x Earliblue & 37,7 & 53,4 & 38,0 & 50,5 \\
\hline 22 & $5 \backslash 2$ & Draper x KazPliszka & 46,3 & 61,9 & 54,2 & 66,9 \\
\hline 23 & $5 \backslash 3$ & Draper $\mathrm{x}$ Toro & 45,6 & 60,2 & 49,1 & 60,7 \\
\hline 24 & $5 \backslash 4$ & Draper x Polaris & 32,3 & 43,6 & 38,4 & 43,3 \\
\hline 25 & $5 \backslash 5$ & Draper x Weymouth & 40,7 & 56,8 & 41,1 & 55,4 \\
\hline \multicolumn{3}{|c|}{ średnia average } & 40,5 & 55,2 & 44,2 & 55,4 \\
\hline 26 & $6 \backslash 1$ & Duke x Earliblue & 49,9 & 63,2 & 48,5 & 61,0 \\
\hline 27 & $6 \backslash 2$ & Duke $\mathrm{x}$ Polaris & 40,6 & 55,2 & 40,8 & 51,4 \\
\hline 28 & $6 \backslash 3$ & Duke x KazPliszka & 36,3 & 48,6 & 39,9 & 50,2 \\
\hline 29 & $6 \backslash 4$ & Duke $\mathrm{x}$ Toro & 46,3 & 65,3 & 51,0 & 69,5 \\
\hline 30 & $6 \backslash 5$ & Duke x Weymouth & 51,2 & 68,5 & 54,1 & 64,9 \\
\hline \multicolumn{3}{|c|}{ średnia average } & 44,9 & 60,2 & 46,9 & 59,4 \\
\hline 31 & $7 \backslash 1$ & Northland x Earliblue & 42,5 & 49,6 & 47,8 & 51,6 \\
\hline 32 & $7 \backslash 2$ & Northland x KazPliszka & 28,6 & 41,1 & 34,1 & 42,7 \\
\hline 33 & $7 \backslash 3$ & Northland $\mathrm{x}$ Polaris & 32,9 & 40,5 & 35,5 & 43,9 \\
\hline 34 & $7 \backslash 4$ & Northland $\mathrm{x}$ Toro & 44,2 & 66,2 & 50,7 & 66,6 \\
\hline 35 & $7 \backslash 5$ & Northland $\mathrm{x}$ Weymouth & 50,1 & 65,3 & 56,8 & 68,2 \\
\hline \multicolumn{3}{|c|}{ średnia average } & 39,7 & 52,6 & 45,0 & 54,6 \\
\hline
\end{tabular}

${ }^{a}$ - I termin - ocena wykonana 15-16.05.2019 r., ${ }^{b}$ - II termin - ocena wykonana 22-24.10.2019 r.

${ }^{a}-1^{\text {st }}$ term - evaluation done on 15-16.05.2019, ${ }^{b}-2^{\text {nd }}$ term - evaluation done on $22-24.10 .2019$. 
Tabela 3

Table 3

Wartości efektów GCA 12 odmian rodzicielskich borówki wysokiej dla sily wzrostu siewek w doświadczeniu

Values of GCA effects of 12 highbush blueberry parental cultivars for seedling's growth in the experiment

\begin{tabular}{|c|c|c|c|c|c|}
\hline \multirow[b]{2}{*}{$\begin{array}{l}\text { Nr matki lub ojca } \\
\text { No of mother } \\
\text { or father }\end{array}$} & \multirow[b]{2}{*}{$\begin{array}{l}\text { Formy rodzicielskie } \\
\text { Parental forms }\end{array}$} & \multicolumn{2}{|c|}{$\begin{array}{c}\text { Wysokość roślin }(\mathrm{cm})^{a} \\
\text { Plant height }(\mathrm{cm})\end{array}$} & \multicolumn{2}{|c|}{$\begin{array}{l}\text { Szerokość roślin }(\mathrm{cm})^{\text {a }} \\
\text { Plant width }(\mathrm{cm})\end{array}$} \\
\hline & & $\begin{array}{l}\text { Ocena efektu } \\
\text { głównego } \\
\text { Main effect } \\
\text { evaluation }\end{array}$ & $\begin{array}{l}\text { Statystyka F dla } \\
\text { efektu głównego } \\
\text { F statistics } \\
\text { for the main effect }\end{array}$ & $\begin{array}{l}\text { Ocena efektu } \\
\text { głównego } \\
\text { Main effect evalu- } \\
\text { ation }\end{array}$ & $\begin{array}{c}\text { Statystyka } F \\
\text { dla efektu głównego } \\
\text { F statistics } \\
\text { for the main effect }\end{array}$ \\
\hline \multicolumn{6}{|c|}{ Analiza względem form matecznych Analysis in relation to maternal forms (\$) } \\
\hline 1 & Aurora & $-3,34$ & 2,70 & $-3,02$ & 2,88 \\
\hline 2 & Bluecrop & $12,31 * *$ & 36,67 & $9,80 * *$ & 30,44 \\
\hline 3 & Brigitta Blue & $-9,22 * *$ & 20,57 & $-7,11 * *$ & 16,01 \\
\hline 4 & Chandler & $-5,37$ & 6,98 & $-6,25 * *$ & 12,39 \\
\hline 5 & Draper & 1,09 & 0,29 & 1,10 & 0,38 \\
\hline 6 & Duke & $6,08^{*}$ & 8,94 & $5,14^{*}$ & 8,36 \\
\hline 7 & Northland & $-1,55$ & 0,58 & 0,34 & 0,04 \\
\hline \multirow{3}{*}{\multicolumn{2}{|c|}{$\begin{array}{c}\text { Wartości krytyczne dla testowania } \\
\text { indywidualnego na poziomie } \\
\text { Critical values for individual testing at } \\
\text { the level }\end{array}$}} & 0,10 & 2,76 & 0,10 & 2,76 \\
\hline & & 0,05 & 3,93 & 0,05 & 3,93 \\
\hline & & 0,01 & 6,89 & 0,01 & 6,89 \\
\hline \multirow{3}{*}{\multicolumn{2}{|c|}{$\begin{array}{c}\text { Wartości krytyczne dla testowania } \\
\text { jednoczesnego na poziomie } \\
\text { Critical values for simultaneous testing at } \\
\text { the level }\end{array}$}} & 0,10 & 6,21 & 0,10 & 6,21 \\
\hline & & 0,05 & 7,54 & 0,05 & 7,54 \\
\hline & & 0,01 & 10,75 & 0,01 & 10,75 \\
\hline \multicolumn{6}{|c|}{ Analiza względem form ojcowskich Analysis in relation to paternal forms (o') } \\
\hline 8 & Earliblue & $-1,44$ & 0,75 & $-0,53$ & 0,13 \\
\hline 9 & KazPliszka & $-4,91 *$ & 8,76 & $-4,01 *$ & 7,64 \\
\hline 10 & Polaris & 2,90 & 3,05 & 2,00 & 1,91 \\
\hline 11 & Toro & 2,82 & 2,88 & 2,47 & 2,90 \\
\hline 12 & Weymouth & 0,63 & 0,15 & 0,06 & 0,00 \\
\hline \multirow{3}{*}{\multicolumn{2}{|c|}{$\begin{array}{c}\text { Wartości krytyczne dla testowania } \\
\text { indywidualnego na poziomie } \\
\text { Critical values for individual testing at } \\
\text { the level }\end{array}$}} & 0,10 & 2,76 & 0,10 & 2,76 \\
\hline & & 0,05 & 3,93 & 0,05 & 3,93 \\
\hline & & 0,01 & 6,89 & 0,01 & 6,89 \\
\hline \multirow{3}{*}{\multicolumn{2}{|c|}{$\begin{array}{l}\text { Wartości krytyczne dla testowania } \\
\text { jednoczesnego na poziomie } \\
\text { Critical values for simultaneous testing at } \\
\text { the level }\end{array}$}} & 0,10 & 5,59 & 0,10 & 5,59 \\
\hline & & 0,05 & 6,89 & 0,05 & 6,89 \\
\hline & & 0,01 & 10,06 & 0,01 & 10,06 \\
\hline
\end{tabular}

* - wartości efektów GCA istotnie różne od zera przy poziomie $\alpha=0,05$

* - values of GCA effects significantly different from zero at the level of $\alpha=0.05$

**- wartości efektów GCA istotnie różne od zera przy poziomie $\alpha=0,01$

** - values of GCA effects significantly different from zero at the level of $\alpha=0.01$

a - na podstawie średnich wyników pomiaru siewek wykonanego w II terminie, jesienia 2019 roku

a - based on average results of seedling measurement done in the second term, in autumn 2019 


\section{Wartości efektów SCA dla sily wzrostu siewek borówki wysokiej należących do 35 rodzin mieszańcowych}

Values of SCA effects for the growth of highbush blueberry seedlings belonging to 35 hybrid families

\begin{tabular}{|c|c|c|c|c|c|}
\hline \multirow{2}{*}{$\begin{array}{l}\text { Nr rodziny } \\
\text { mieszańcowej } \\
\text { No of hybrid } \\
\text { family }\end{array}$} & \multirow[b]{2}{*}{$\begin{array}{l}\text { Krzyżowane formy rodziciel- } \\
\text { skie } \\
\text { Crossed parental forms }\end{array}$} & \multicolumn{2}{|c|}{$\begin{array}{l}\text { Wysokość roślin }(\mathrm{cm})^{a} \\
\text { Plant height }(\mathrm{cm})\end{array}$} & \multicolumn{2}{|c|}{$\begin{array}{l}\text { Szerokość roślin }(\mathrm{cm})^{a} \\
\text { Plant width }(\mathrm{cm})\end{array}$} \\
\hline & & $\begin{array}{l}\text { Ocena efektu } \\
\text { głównego } \\
\text { Main effect value }\end{array}$ & $\begin{array}{c}\text { Statystyka F dla } \\
\text { efektu głównego } \\
\text { F statistics } \\
\text { for the main effect }\end{array}$ & $\begin{array}{l}\text { Ocena efektu } \\
\text { głównego } \\
\text { Main effect value }\end{array}$ & $\begin{array}{c}\text { Statystyka F dla } \\
\text { efektu głównego } \\
\text { F statistics } \\
\text { for the main effect }\end{array}$ \\
\hline 1 & Aurora x Earlibblue & 3,26 & 0,64 & 6,68 & 3,53 \\
\hline 2 & Aurora x KazPliszka & $-2,92$ & 0,52 & $-1,54$ & 0,19 \\
\hline 3 & Aurora x Polaris & $12,87^{*}$ & 10,03 & $12,05^{*}$ & 11,51 \\
\hline 4 & Aurora x Toro & 5,40 & 1,77 & 0,45 & 0,02 \\
\hline 5 & Aurora x Weymouth & $-18,61^{* *}$ & 20,97 & $-17,64 * *$ & 24,66 \\
\hline 6 & Bluecrop x Earliblue & $-4,49$ & 1,22 & $-7,53$ & 4,50 \\
\hline 7 & Bluecrop x KazPliszka & 5,64 & 1,92 & 6,15 & 3,00 \\
\hline 8 & Bluecrop x Polaris & $-2,40$ & 0,35 & $-3,34$ & 0,88 \\
\hline 9 & Bluecrop x Toro & $-0,04$ & 0,00 & $-2,43$ & 0,47 \\
\hline 10 & Bluecrop x Weymouth & 1,29 & 0,10 & 7,16 & 4,06 \\
\hline 11 & Brigitta B. x Earliblue & 3,34 & 0,67 & 11,42 & 10,34 \\
\hline 12 & Brigitta B. x KazPliszka & 1,74 & 0,18 & $-0,73$ & 0,04 \\
\hline 13 & Brigitta B. x Polaris & $-3,65$ & 0,80 & $-3,89$ & 1,20 \\
\hline 14 & Brigitta B. x Toro & $-6,62$ & 2,65 & $-8,28$ & 5,44 \\
\hline 15 & Brigitta B. x Weymouth & 5,19 & 1,63 & 1,48 & 0,17 \\
\hline 16 & Chandler x Earliblue & $-4,71$ & 1,35 & $-5,86$ & 2,73 \\
\hline 17 & Chandler x KazPliszka & $-9,49$ & 5,45 & $-7,56$ & 4,53 \\
\hline 18 & Chandler x Polaris & $20,40 * *$ & 25,2 & $15,76^{* *}$ & 19,69 \\
\hline 19 & Chandler $\mathrm{x}$ Toro & 2,56 & 0,40 & 7,61 & 4,60 \\
\hline 20 & Chandler x Weymouth & $-8,76$ & 4,64 & $-9,95$ & 7,85 \\
\hline 21 & Draper x Earliblue & $-0,37$ & 0,01 & $-4,34$ & 1,49 \\
\hline 22 & Draper x KazPliszka & 11,63 & 8,19 & $15,54 * *$ & 19,16 \\
\hline 23 & Draper x Polaris & 2,12 & 0,27 & 3,31 & 0,87 \\
\hline 24 & Draper x Toro & $-14,40 *$ & 12,55 & $-14,51 * *$ & 16,7 \\
\hline 25 & Draper x Weymouth & 1,01 & 0,06 & 0,00 & 0,00 \\
\hline 26 & Duke $\mathrm{x}$ Earliblue & 4,49 & 1,22 & 2,13 & 0,36 \\
\hline 27 & Duke x KazPliszka & $-0,06$ & 0,00 & $-3,99$ & 1,26 \\
\hline 28 & Duke x Polaris & $-14,44 *$ & 12,62 & $-11,18$ & 9,91 \\
\hline 29 & Duke x Toro & 2,29 & 0,32 & 7,60 & 4,59 \\
\hline 30 & Duke x Weymouth & 7,72 & 3,61 & 5,44 & 2,35 \\
\hline 31 & Northland $\mathrm{x}$ Earliblue & $-1,51$ & 0,14 & $-2,48$ & 0,49 \\
\hline 32 & Northland x KazPliszka & $-6,53$ & 2,58 & $-7,87$ & 4,91 \\
\hline 33 & Northland x Polaris & $-14,92 *$ & 13,47 & $-12,71 *$ & 12,81 \\
\hline 34 & Northland $\mathrm{x}$ Toro & 10,81 & 7,08 & 9,55 & 7,23 \\
\hline 35 & Northland x Weymouth & 12,15 & 8,93 & $13,51 * *$ & 14,48 \\
\hline 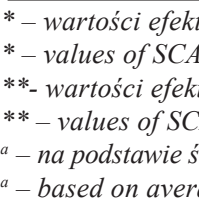 & $\begin{array}{l}\text { SCA istotnie różne od zera prz. } \\
\text { fects significantly different from } \\
\text { v SCA istotnie różne od zera prz } \\
\text { effects significantly different fror } \\
\text { lnich wyników pomiaru siewek w } \\
\text { e results of seedling measuremer }\end{array}$ & $\begin{array}{l}\text { oziomie } \alpha=0,05 \\
\text { ro at the level of } \alpha \\
\text { oziomie } \alpha=0,01 \\
\text { ero at the level of } \alpha \\
\text { nanego } w \text { II termin } \\
\text { lone in the second } t\end{array}$ & $\begin{array}{l}05 \\
0.01 \\
\text { jesienia } 2019 \text { roku } \\
\text {, in autumn } 2019\end{array}$ & & \\
\hline
\end{tabular}


Tabela 4 cd.

Table 4 cd.

Wartości efektów SCA dla siły wzrostu siewek borówki wysokiej należących do 35 rodzin mieszańcowych

Values of SCA effects for the growth of highbush blueberry seedlings belonging to 35 hybrid families

\begin{tabular}{|c|c|c|c|c|c|}
\hline \multirow{2}{*}{$\begin{array}{l}\text { Nr rodziny } \\
\text { mieszańcowej } \\
\text { No of hybrid } \\
\text { family }\end{array}$} & \multirow[b]{2}{*}{$\begin{array}{l}\text { Krzyżowane formy rodziciel- } \\
\text { skie } \\
\text { Crossed parental forms }\end{array}$} & \multicolumn{2}{|c|}{$\begin{array}{l}\text { Wysokość roślin }(\mathrm{cm})^{\mathrm{a}} \\
\text { Plant height }(\mathrm{cm})\end{array}$} & \multicolumn{2}{|c|}{$\begin{array}{l}\text { Szerokość roślin }(\mathrm{cm})^{\text {a }} \\
\text { Plant width }(\mathrm{cm})\end{array}$} \\
\hline & & $\begin{array}{l}\text { Ocena efektu } \\
\text { głównego } \\
\text { Main effect value }\end{array}$ & $\begin{array}{l}\text { Statystyka F dla } \\
\text { efektu głównego } \\
\text { F statistics } \\
\text { for the main effect }\end{array}$ & $\begin{array}{l}\text { Ocena efektu } \\
\text { głównego } \\
\text { Main effect value }\end{array}$ & $\begin{array}{l}\text { Statystyka F dla } \\
\text { efektu głównego } \\
\text { F statistics } \\
\text { for the main effect }\end{array}$ \\
\hline \multirow{3}{*}{\multicolumn{2}{|c|}{$\begin{array}{l}\text { Wartości krytyczne dla testowania } \\
\text { indywidualnego na poziomie } \\
\text { Critical values for individual testing at the level }\end{array}$}} & 0,10 & 2,76 & 0,10 & 2,76 \\
\hline & & 0,05 & 3,93 & 0,05 & 3,93 \\
\hline & & 0,01 & 6,89 & 0,01 & 6,89 \\
\hline \multirow{3}{*}{\multicolumn{2}{|c|}{$\begin{array}{l}\text { Wartości krytyczne dla testowania jednoczesnego } \\
\text { na poziomie } \\
\text { Critical values for simultaneous testing at the } \\
\text { level }\end{array}$}} & 0,10 & 9,34 & 0,10 & 9,34 \\
\hline & & 0,05 & 10,75 & 0,05 & 10,75 \\
\hline & & 0,01 & 14,12 & 0,01 & 14,12 \\
\hline
\end{tabular}

* - wartości efektów SCA istotnie różne od zera przy poziomie $\alpha=0,05$

* - values of SCA effects significantly different from zero at the level of $\alpha=0.05$

**-wartości efektów SCA istotnie różne od zera przy poziomie $\alpha=0,01$

** - values of SCA effects significantly different from zero at the level of $\alpha=0.01$

a - na podstawie średnich wyników pomiaru siewek wykonanego w II terminie, jesienia 2019 roku

a - based on average results of seedling measurement done in the second term, in autumn 2019

\section{Dyskusja}

\section{Ocena fenotypowa siewek}

Borówka amerykańska (wysoka, północnego typu) ma specyficzne wymagania $\mathrm{w}$ uprawowe. Prawidłowy wzrost i rozwój, kwitnienie oraz plonowanie roślin i wielkość (masa) owoców uzależnione są od czynników genetycznych (genotypu) i warunków środowiska oraz ich współdziałania (interakcji). Współdziałanie genotypu i środowiska (GxE) jest zjawiskiem biologicznym, które definiuje się w kategoriach jego mechanizmów lub zazwyczaj jego efektów fenotypowych dla danej cechy. Jest więc ona określana jako niejednakowa reakcja genotypów na warunki środowiskowe (miejscowości w poszczególnych latach, miejscowości średnio $\mathrm{w}$ latach, lata $\mathrm{w}$ poszczególnych miejscowościach, lata średnio w miejscowościach) albo jako niejednakowe różnice średnich genotypowych w różnych środowiskach (Mądry i in., 2006).

Do drugiej grupy czynników należy zaliczyć: wybór odpowiedniego stanowiska, kwaśną glebę (pH 4,5-5,5) i jej przygotowanie (wzbogacenie w substancję organiczną) oraz wszystkie zabiegi pielęgnacyjne i agrotechniczne, w tym niezbędne nawadnianie kroplowe (Smolarz, 2003; 2006; Smolarz i Pluta, 2014). Bardzo ważny jest także wpływ czynników genetycznych, gdyż odmiany (genotypy) borówki wysokiej różnią się pod względem siły wzrostu i innych cech użytkowych.

W naszych badaniach stwierdzono wpływ genotypów rodzicielskich borówki wysokiej, używanych $\mathrm{w}$ programie krzyżowań, na siłę wzrostu ocenianej populacji siewek (potomstwa). Wykonana ocena fenotypowa siewek pod kątem w/w cechy morfologicznej roślin była często zgodna z opisami i charakterystyką pomologiczną odmian rodzicielskich borówki wysokiej (Smolarz, 2000; Pliszka, 2002). Ocena siły wzrostu wszystkich siewek w doświadczeniu polowym była zróżnicowana i uzależniona od pochodzenia (odmian rodzicielskich). Uzyskane wyniki oceny fenotypowej (obserwacje i pomiary roślin) siewek potwierdziły przydatność niektórych genotypów rodzicielskich do poprawy siły wzrostu u potomstwa ocenianych roślin. Jest to ważna cecha, gdyż na ogół siewki borówki wysokiej charakteryzują się powolnym i słabszym wzrostem, w porównaniu do siewek porzeczki czarnej i maliny.

\section{Efekty GCA i SCA}

W 2019 roku wykonano badania nad wartością fenotypową i genetyczną populacji siewek borówki wysokiej na podstawie indywidualnej oceny ich siły wzrostu (pomiar wysokości i szerokości roślin). Potencjał genetyczny wybranych 12 odmian (form) rodzicielskich do programu krzyżowań w układzie czynnikowym (7 - matecznych i 5 - ojcowskich) określono za pomocą ogólnej (GCA) i specyficznej (SCA) zdolności kombinacyjnej (Griffing, 1956 a, b; Mądry i Ubysz-Borucka, 1982; Ubysz-Borucka $i$ in. 1985).

Ogólna zdolność kombinacyjna (GCA) pod względem rozpatrywanej cechy określa ogólną przydatność form rodzicielskich do tworzenia 
nowych odmian roślin uprawnych. Specyficzna zdolność kombinacyjna (SCA) dla rozpatrywanej cechy odnosi się do pary form rodzicielskich i jest interakcją (współdziałaniem) obu form rodzicielskich, ujawnianą w postaci zachowania tej cechy $\mathrm{w}$ potomstwie. Istotnie pozytywne lub negatywne efekty SCA oszacowane są tylko w niektórych kombinacjach krzyżowań i wskazują na poprawę (dodatnie) lub pogorszenie (ujemne) wartości cech u potomstwa. Wysokie i istotne wartości efektów SCA, stwierdzone w poszczególnych populacjach mieszańcowych dotyczą najczęściej pojedynczych cech użytkowych roślin (Spangelo i in., 1971).

W praktyce najwartościowsze potomstwo pod względem pożądanej cechy uzyskuje się w wyniku krzyżowania form rodzicielskich, które odznaczają się istotnymi i dodatnimi (pozytywnymi) wartościami efektów GCA (Griffing, 1956 a, b). W naszych badaniach genetycznych stwierdzono, że wśród 12 genotypów rodzicielskich $(7 \times 5)$ borówki wysokiej większość form matecznych miało istotne (na plus lub minus) wartości efektów GCA dla badanych cechy morfologicznych roślin. W przypadku siły wzrostu dla odmian: 'Bluecrop' i 'Duke' oszacowano istotne i dodatnie efekty GCA, a dla 'Brigitta Blue', 'Chandler' i 'KazPliszka' istotne i ujemne efekty GCA. Odmiany te użyte $w$ programach krzyżowań są z dużym prawdopodobieństwem donorami cech wytwarzania wyższych/niższych lub węższych/ szerszych krzewów u potomstwa. Oszacowane wartości efektów GCA 12 wybranych form rodzicielskich borówki wysokiej oraz wyniki oceny fenotypowej badanych cech siewek rosnących w doświadczeniu polowym są często skorelowane. $\mathrm{Na}$ przykład siewki, które w swoim rodowodzie miały odmiany 'Bluecrop' lub 'Duke', charakteryzowały się silniejszym wzrostem, w porównaniu do ogólnej średniej wartości dla tej cechy morfologicznej roślin.

Wartość efektów SCA i ich zróżnicowanie w obrębie badanego układu krzyżowań świadczy o dużym znaczeniu genetycznego współdziałania obu form rodzicielskich $\mathrm{w}$ uwarunkowaniu cech w potomstwie (Baker, 1978). Wysokie i istotne statystycznie wartości efektów SCA, stwierdzone w konkretnych krzyżowaniach (rodzinach mieszańców), dotyczą najczęściej pojedynczych cech użytkowych. Sprawia to, że uzyskanie nowych odmian o poprawionych kilku cechach jednocześnie jest bardzo trudne, jak np. u truskawki (Spangelo i in., 1971; Hortyński, 1987; Simpson i Sharp, 1988; Masny i in., 2008, Żurawicz, 1990), czy porzeczki czarnej (Pluta, 1994; Żurawicz i in., 1996; Mądry i in., 2004; Pluta i in., 1993; 2008).

W naszych badaniach nad zdolnością kombinacyjną 12 form rodzicielskich borówki wysokiej stwierdzono kilka istotnych wartości efektów SCA (dodatnie lub ujemne) dla siły wzrostu siewek. Dla tej cechy (określonej jako wysokość i szerokość roślin) istotnie dodatnie wartości efektów SCA dla wysokości roślin oszacowano tylko dla 2 rodzin mieszańców, a istotnie ujemne dla innych 4 rodzin. Więcej istotnych efektów SCA oszacowano dla szerokości siewek, dla 4 rodzin mieszańców były to wartości dodatnie, zaś dla 3 rodzin - ujemne. Oznacza to, że genetyczne współdziałanie obu genotypów rodzicielskich w ramach tych rodzin mieszańcowych warunkuje $\mathrm{z}$ dużym prawdopodobieństwem wysoki/niski lub szeroki/wąski charakter wzrostu u potomstwa (siewek). Należy podkreślić, że wyniki oceny fenotypowej w/w cech morfologicznych siewek borówki wysokiej rosnących w doświadczeniu były zgodne w większości przypadków z oszacowanymi wartościami efektów SCA rozpatrywanych rodzin mieszańcowych.

W przeglądzie krajowej literatury brak jest informacji i doniesień naukowych dotyczących zdolności kombinacyjnej form (genotypów) rodzicielskich borówki wysokiej. Podobnie literatura zagraniczna przedstawiająca te zagadnienia dla omawianego gatunku uprawnego jest bardzo uboga. Jest to związane głównie z trudnościami wykonania kompletnego programu krzyżowań (układ dialleliczny lub czynnikowy) i uzyskania dużej populacji siewek $F_{1}$ do oceny fenotypowej. Barierą do prowadzenia tego typu badań jest także duża pracochłonność wykonania indywidualnej obserwacji, pomiarów i oceny wielu cech użytkowych dla kilku tysięcy siewek, co jest powiązane $\mathrm{z}$ dużymi nakładami finansowymi.

Na podstawie uzyskanych wyników badań określono wartość hodowlaną oraz przydatność wybranych form rodzicielskich do programów krzyżowań borówki wysokiej, w celu uzyskania wartościowego potomstwa. W wyniku przeprowadzonej oceny fenotypowej i genotypowej populacji siewek pokolenia $F_{1}$ wyselekcjonowano ponad 30 wartościowych pojedynków, które posadzone będą w kolekcji klonów.

\section{Wnioski}

1. Ocena fenotypowa siewek borówki wysokiej wskazuje na ich zróżnicowanie pod względem siły wzrostu.

2. Badane odmiany rodzicielskie borówki wysokiej różnią się zdolnością kombinacyjną (efekty GCA i SCA) pod względem ocenianej cechy 
morfologicznej siewek.

3. Oszacowane wartości efektów GCA dla 12 wybranych odmian (form) rodzicielskich borówki wysokiej oraz efektów SCA dla 35 rodzin mieszańcowych przyjmują wartości dodatnie i ujemne. Zatem odmiany te, użyte w programach krzyżowań, mogą przyczynić się do poprawy lub pogorszenia wartości analizowanej cechy u potomstwa.

Badania finansowano ze środków projektu MRiRW: Badania podstawowe na rzecz postepu biologicznego w produkcji roślinnej, decyzja HOR. hn.802.4.2019 z dnia 14.05.2019 r., Zadanie nr 72.

\section{Literatura}

Baker, R.J. (1978) . Issues in diallel analysis. Crop Science, 18 (4): 533-536. http://dx.doi.org/10.2135/cropsci1978. 0011183x001800040001x

Bestfleisch, M., Möhring, J., Hanke, M.V. (2014). A diallel crossing approach aimed on selection for ripening time and yield in breeding of new strawberry (Fragaria $\times$ ananassa Duch.) cultivars. Plant Breeding 133: 115-120. https://doi.org/10.1111/pbr.12120

Caliński, T., Czajka, S., Kaczmarek, Z., Krajewski, P. (2003). Podręcznik użytkowania programu SERGEN 4. Metodyka statystyczna i obsługa programu SERGEN (Wersja 4 dla Windows) przeznaczonego do serii doświadczeń odmianowych i genetyczno-hodowlanych. Wyd. IGR PAN w Poznaniu. ss 77.

Griffing, B. (1956)a. A generalised treatments of diallel crosses in quantitative inheritance. Heredity 10:31-50 http://dx.doi.org/10.1038/hdy.1956.2

Griffing, B. (1956)b. Concept of general and specific combining ability in relation to diallel crossing systems. Austr. J. Biol. Sci. 9: 463-493. http://dx.doi.org/10.1071/ bi9560463

Hortyński, J.A., 1987. Dziedziczenie niektórych cech ilościowych truskawki (Fragaria x ananassa Duch.). Metody i problemy oszacowań. Praca hab. Wyd. AR Lublin.

Masny, A., Mądry, W., Żurawicz, E. (2005). Combining ability analysis of fruit field and fruit quality in ever-bearing strawberry cultivars using an incomplete diallel cross design. Journal of Fruit and Ornamental Plant Research 13: 5-17.

Masny, A., Mądry, W., Żurawicz, E. (2008). Combining ability for important horticultural traits in medium and late-maturing strawberry cultivars. Journal of Fruit and Ornamental Plant Research 16: 133-152.

Masny, A., Mądry, W., Żurawicz, E. (2014). Combining ability of selected dessert strawberry cultivars with different fruit ripening periods. Acta Scientiarum Polonorum Hortorum Cultus 13 (1): 67-78.

Masny, A., Pruski, K., Żurawicz, E., Mądry, W. (2016). Breeding value of selected dessert strawberry (Fragaria $\times$ ananassa Duch.) cultivars for ripening time, fruit yield and quality. Euphytica 207: 224-243. http://dx.doi. org/10.1007/s10681-016-1690-6

Mądry, W., Ubysz-Borucka, L. (1982). Biometryczna analiza zdolności kombinacyjnej w niekompletnym układzie diallel cross. Cz. I. Model stały dla cech ilościowych. Rocz. Nauk Roln. Ser. A 105: 9-27.

Mądry, W., Krajewski, P., Pluta, S., Żurawicz, E. (2004). Wielocechowa analiza wartości hodowlanej i zróżnicowania genetycznego odmian porzeczki czarnej (Ribes nigrum L.) na podstawie efektów ogólnej zdolności kombinacyjnej. Acta Scient. Polon. Hortorum. Cultus 3: 93-109.

Mądry, W., Talbot, M., Ukalski, K., Drzazga, T., Iwańska, M. (2006). Podstawy teoretyczne znaczenia efektów genotypowych i interakcyjnych w hodowli roślin na przykładzie pszenicy ozimej. Biuletyn IHAR, nr 240/241: $13-32$.

Pliszka, K. (2002). Borówka wysoka, czyli amerykańska. Wyd. Działkowiec sp. z o.o. Warszawa.

Pluta, S., Mądry, W., Żurawicz, E. (1993). Zdolność kombinacyjna w hodowli twórczej porzeczki czarnej. Zeszyty Naukowe AR we Wrocławiu, Rolnictwo LVIII, nr 223: 367-373.

Pluta, S. (1994). Analiza dialleliczna wybranych form rodzicielskich porzeczki czarnej (Ribes nigrum L.) pod względem najważniejszych cech użytkowych. Praca doktorska, Instytut Sadownictwa i Kwiaciarstwa w Skierniewicach.

Pluta, S., Mądry, W., Zurawicz, E. (2008). General combining ability of selected blackcurrant (Ribes nigrum L.) genotypes in breeding for dessert quality fruit Acta Hort. 777: 57-62. http:// dx.doi.org/10.17660/actahortic.2008.777.4.

Pluta, S., Studnicki, M., Mądry, W., Żurawicz, E. (2014). Combining Ability Analysis for Selected Plant Traits in Gooseberry. J. Amer. Soc. Hort. Sci. 139: 325-335. http://dx.doi.org/10.21273/jashs.139.3.325

Pluta, S. and Żurawicz, E. (2014). The high-bush (Vaccinium corymbosum L.) breeding programme in Poland. Acta Hort. 1017:177-180 http://dx.doi.org/10.17660/actahortic.2014.1017.20.

Sherrif, N.M., Appadurai, R., Rangasamy, M. (1985). Combining ability in sunflower. Indian, J. Agric. Sci. 55: $315-318$

Simpson, D.W. and Sharp, D.S. (1988). The inheritance of fruit yield and stolon production in everbearing strawberries. Euphytica 38: 65-74. http://dx.doi.org/10.1007/ bf00024812.

Smolarz, K. (2000). Borówka wysoka. Zeszyty Pomologiczne. ISK Skierniewice.

Smolarz, K. (2003). Wybór i przygotowanie pola pod plantację borówki. Hasło Ogrodnicze 10: 61-62.

Smolarz, K. (2006). History of highbush blueberry ( $V$. corym- 
bosum L.) growing in Poland. Acta Hort. 715: 313-316. http://dx.doi.org/10.17660/actahortic.2006.715.46.

Smolarz, K. and Pluta, S. (2014). Cultivation of the high-bush blueberry in Poland. Acta Hort. 1017: 199-204 http:// dx.doi.org/10.17660/actahortic.2014.1017.24.

Spangelo, L.P., Watkins, R., Hsu, C.S., Fejer, S.O. (1971). Combining ability analysis in the cultivated strawberry. Can. J. Plant Sci. 51: 377-383 http://dx.doi.org/10.4141/ cjps71-075.

Sprague, G.F. and Tatum, L.A. (1942). General vs. Specific combination ability in single crosses of corn. J. Amer. Soc. Agron. 34: 923-932 http://dx.doi.org/10.2134/agronj 1942.00021962003400100008x.

Ubysz-Borucka, L., Mądry, W., Muszyński, S. (1985). Podstawy statystyczne genetyki cech ilościowych whodowli roślin. Wydawnictwo SGGW-AR, Warszawa: ss 220 .
Vieira, R.A., Scapim, C.A., Moterle, L.M., Tessmann, D.J., Conrado, T.V., Amaral Jnior, A.T. (2009). Diallel analysis of leaf disease resistance in inbred Brazilian popcorn cultivars. Genetics and Molecular Research. Genetics and Molecular Research 8 (4): 1427-36 http://dx.doi. org/10.4238/vol8-4gmr655

Żurawicz, E. (1990). Dziedziczenie najważniejszych cech użytkowych truskawki (Fragaria $x$ ananassa Duch.). Praca hab., ISK Skierniewice.

Żurawicz, E., Mądry, W., Pluta, S. (1996). Variation and heritability of economically important traits in black currant (Ribes nigrum L.) evaluated in a diallel cross design. Euphytica 91: 219-224.

Żurawicz, E., Masny, A., Madry, W. (2006). Usefulness of selected strawberry (Fragaria-ananassa) genotypes for breeding late ripening cultivars. Acta Hort. 708:501505 http://dx.doi.org/10.17660/actahortic.2006.708.88. 